\title{
PENGARUH MODAL KERJA TERHADAP RETURN ON ASSET (ROA) MELALUI PENJUALAN
}

\author{
Effect Against Working Capital Return On Asset (ROA) Through Sales
}

\author{
Zaenal Abidin, Daryono Setiadi \\ Manajemen FE Unwir \\ daryonosetiadife@unwir.ac.id
}

\begin{abstract}
ABSTRAK
Penelitian ini bertujuan untuk mengetahui seberapa besar pengaruh modal kerja terhadap penjualan, penjualan terhadap Return On Asset (ROA) pada PD. Sri Tanjung Indramayu.

Metode yang digunakan pada penelitian ini adalah metode deskriptif asosiatif dengan pendekatan kuantitatif. Dikatakan pendekatan kuantitatif sebab pendekatan yang digunakan di dalam usulan penelitian, proses hipotesis, analisa data dan kesimpulan data sampai dengan penulisannya menggunakan aspek pengukuran, perhitungan, rumus dan kepastian data numerik, untuk teknik analisis data yang dipakai diantaranya analisis korelasi, analisis koefisien determinasi, dan uji hipotesis (uji t).

Berdasarkan hasil analisis yang diperoleh dari analisis koefisien korelasi antara $\left(X_{1}\right)$ modal kerja terhadap $\left(X_{2}\right)$ penjualan sebesar 0.897 yang berarti antara variabel modal kerja terhadap penjualan mempunyai pengaruh yang sangat kuat. hasil analisis $\left(\mathbf{X}_{2}\right)$ penjualan terhadap $(Y)$ return on asset sebesar 0.948 yang berarti antara variabel penjualan terhadap return on asset mempunyai hubungan yang sangat kuat dan positif.

Berdasarkan hasil analisis yang diperoleh dari analisis koefisien determinasi $\left(X_{1}\right)$ modal kerja terhadap $\left(\mathrm{X}_{2}\right)$ penjualan pada $\mathrm{PD}$. Sri Tanjung Indramayu adalah sebesar $80.46 \%$ sedangkan sisanya $19.54 \%$ diberikan oleh faktor lain yang tidak diteliti dalam penelitian ini. Analisis koefisien determinasi $\left(\mathbf{X}_{2}\right)$ penjualan terhadap $(\mathbf{Y})$ return on asset pada PD. Sri Tanjung Indramayu adalah sebesar $89.87 \%$ sedangkan sisanya $10.13 \%$ diberikan oleh faktor lain yang tidak diteliti dalam penelitian ini.
\end{abstract}

Berdasarkan hasil perhitungan uji t $\left(\mathbf{X}_{\mathbf{1}}\right)$ terhadap $\left(X_{2}\right)$ maka diperoleh nilai t_hitung sebesar 4.058 dan didapatkan nilai t_tabel sebesar 2.776 yang berarti karena t_hitung lebih besar dari t_tabel (4.058 > 2.776), maka HO di tolak dan Ha di terima, sehingga modal kerja berpengaruh terhadap penjualan. Perhitungan uji $t\left(X_{2}\right)$ terhadap (Y) diperoleh nilai t_hitung sebesar 5.961 dan nilai t_tabel sebesar 2.776 karena t_hitung lebih besar dari t tabel $(5.961>2.776)$, maka $\mathrm{H}_{2} \mathrm{O}$ di tolak dan $\mathrm{H}_{2}$ a di terima, sehingga menyatakan bahwa penjualan berpengaruh terhadap Return On asset pada PD. Sri Tanjung Indramayu.

Kata Kunci: Modal Kerja, Return On Asset dan Penjualan.

\section{ABSTRACT}

This study aims to determine how much influence the working capital to sales, sales to the Return On Asset (ROA) in PD. Sri Tanjung Indramayu.

The method used in this research is descriptive method with quantitative approach associative. It said quantitative approach because the approach used in the proposed research, the process of hypothesis, data analysis and inference data up to the writing used aspects of measurements, calculations, formulas and certainty of numerical data, for data analysis techniques used include correlation analysis, coefficient of determination analysis, and hypothesis test ( $t$ test).

Based on the analysis results obtained from the analysis of the correlation coefficient between $\left(\mathbf{X}_{1}\right)$ of working capital to $\left(\mathbf{X}_{2}\right)$ sales by 0897 , which means between the variable working capital to sales has a very strong influence. the results of the analysis $\left(\mathrm{X}_{2}\right)$ of sales to $(\mathrm{Y})$ return on assets for 0948, which means between the variable return on asset sales to have a very strong relationship and positive.

Based on the analysis results obtained from the analysis of the coefficient of determination $\left(\mathbf{X}_{1}\right)$ of working capital to $\left(\mathbf{X}_{2}\right)$ sales in PD. Sri Tanjung Indramayu amounted to $80.46 \%$ while the remaining $19: 54 \%$ by other factors not examined in this study. Coefficient of determination $\left(\mathrm{X}_{2}\right)$ of sales to $(\mathrm{Y})$ return on assets in PD. Sri Tanjung Indramayu amounted to $89.87 \%$ while the remaining $10: 13 \%$ by other factors not examined in this study.

Based on the calculation $t$ test $\left(X_{1}\right)$ to $\left(X_{2}\right)$ the obtained value $t$ _hitung of $\mathbf{4 0 5 8}$ and obtained the value $t$ tabel amounted to 2,776 , which means for $t$ _hitung greater than $t$ _tabel $(4,058>2,776)$, then $\mathrm{HO}$ rejected and $\mathrm{Ha}$ accepted, so that the 
working capital effect on sales. Calculation $t$ test $\left(\mathrm{X}_{2}\right)$ against $(\mathrm{Y})$ values obtained $\mathrm{t}$ _hitung amounted to 5,961 and the value of $t$ tabel of 2776 because t_hitung greater than $t$ _tabel $(5,961>2,776)$, then $\mathrm{H}_{2} \mathrm{O}$ rejected and $\mathrm{H}_{2}$ a received, thus stating that the sale affect the return on assets the PD. Sri Tanjung Indramayu.

Keywords: Working Capita, Return On Asset, Through Sales.

\section{PENDAHULUAN}

Salah satu rasio yang digunakan perusahaan untuk mengukur laba/profit adalah rasio profitabilitas. Profitabilitas merupakan rasio yang bertujuan untuk mengetahui kemampuan perusahaan dalam menghasilkan laba selama periode tertentu. Profitabilitas dapat diterapkan dengan menghitung berbagai tolak ukur yang relevan. Salah satu tolak ukur yang relevan adalah dengan menggunakan rasio keuangan. Return On Asset (ROA) sebagai salah satu alat didalam menganalisis kondisi keuangan hasil operasi dan tingkat profitabilitas perusahaan. Return On Asset (ROA) digunakan untuk mengukur kemampuan perusahaan menghasilkan laba bersih berdasarkan tingkat asset tertentu. Dengan mengetahui ROA, kita dapat menilai apakah perusahaan telah efisien atau tidak dalam menggunakan aktiva kegiatan operasionalnya dalam menghasilkan profit. Dengan kata lain, semakin tinggi rasio ini maka semakin baik produktivitas asset dalam memperoleh keuntungan bersih. Dengan menggunakan perhitungan Return On Asset dapat membantu perusahaan untuk dapat mengukur efisiensi penggunaan modal yang menyeluruh, yang sensitif terhadap setiap hal yang mempengaruhi keadaan keuangan perusahaan sehingga kita dapat mengetahui posisi efektivitas perusahaan.

Modal kerja merupakan hal yang sangat penting bagi perusahaan karena perusahaan selalu membutuhkan modal kerja untuk membiayai operasionalnya sehari-hari, misalnya untuk membeli bahan baku, membiayai upah buruh, gaji pegawai, dan lain sebagainya. Modal kerja harus senantiasa dikelola agar tidak terlalu kecil maupun terlalu besar jumlahnya. Adanya modal kerja yang cukup sangat penting bagi suatu perusahaan, karena dengan modal kerja yang cukup itu memungkinkan bagi perusahaan untuk beroperasi dengan seekonomis mungkin dan perusahaan tidak mengalami kesulitan atau dalam menghadapi bahaya-bahaya yang mungkin timbul karena adanya krisis atau kekacauan dalam hal masalah keuangan. Dengan mengelola modal kerja secara efektif dan effisien diharapkan perusahaan mampu memenuhi kebutuhan operasionalnya.

Penjualan merupakan suatu unsur penting dan merupakan faktor kunci yang menentukan dalam mendukung aktifitas usaha dalam suatu perusahaan. Seperti pada PD. Sri Tanjung yang bergerak dibidang produksi dan penjualan beberapa macam krupuk seperti kerupuk udang, kerupuk bawang, kerupuk ikan dan krupuk jengkol. Begitu pentingnya penjualan produk 
perusahaan, membuat setiap perusahaan tidak menutup kemungkinan bahwa persaingan didunia usaha perdagangan ini sangatlah ketat, perusahaan semua berlombalomba seakan tidak ingin tersaingi oleh pesaingnya, ketika satu perusahaan mengeluarkan produk baru, maka perusahaan lain sejenispun mengikuti persaingan untuk mengeluarkan produk barunya yang serupa dengan kualitas yang lebih disempurnakan guna menjadi pesaing bagi produk sebelumnya agar menarik daya beli konsumen serta mampu bersaing dipasar bebas. Keberhasilan perusahaan dalam penjualan dapat mendongkrak pendapatan perusahaan karena dari adanya penjualan tersebut berarti perusahaan memiliki kemampuan untuk menghasilkan laba dan juga modal untuk membiayai kegiatan operasionalnya.

\section{Identifikasi Masalah}

Seperti yang terdapat dalam latar belakang di atas, disebutkan bahwa Modal Kerja terhadap Return On Asset melalui Penjualan, dari uraian tersebut maka permasalahan yang dapat diidentifikasi sebagai berikut :

1. Seberapa besar Return On Asset pada PD. Sri Tanjung?

2. Bagaimana cara mengoptimalkan Return On Asset pada PD. Sri Tanjung?

3. Seberapa besar modal kerja pada PD. Sri Tanjung?
4. Bagaimana cara pengolahan/penggunaan modal kerja pada PD. Sri Tanjung?

5. Seberapa besar penjualan pada PD. Sri Tanjung?

6. Bagaimana cara memaksimalkan penjualan pada PD. Sri Tanjung?

7. Seberapa besar pengaruh modal kerja terhadap penjualan pada PD. Sri Tanjung?

8. Seberapa besar pengaruh penjualan terhadap Return On Asset pada PD. Sri Tanjung?

\section{TINJAUAN PUSTAKA}

\section{Modal Kerja}

Modal kerja merupakan hal yang sangat penting bagi perusahaan karena perusahaan selalu membutuhkan modal kerja untuk membiayai operasinya sehari-hari, misalnya untuk membeli bahan baku, membiayai upah buruh, gaji pegawai, dan lain sebagainya. Dimana dana yang telah dikeluarkan itu diharapkan dapat kembali lagi masuk dalam perusahaan dalam waktu yang pendek melalui hasil penjualan.

Menurut kasmir (2014:250) menyatakan bahwa :

"Modal kerja diartikan sebagai investasi yang ditanamkan dalam aktiva lancar atau aktiva jangka pendek, seperti kas, Bank, surat-surat berharga, piutang, persediaan, dan aktiva lancar lainnya”.

$$
\text { Menurut Munawir }
$$
menyatakan bahwa : 
"Modal kerja adalah kelebihan aktiva lancar terhadap hutang jangka pendek (Net working capital) yaitu jumlah aktiva lancar yang berasal dari pinjaman jangka panjang maupun dari para pemilik perusahaan".

Sedangkan menurut Irham Fahmi (2014:99) menyatakan bahwa:

"Modal kerja adalah investasi sebuah perusahaan pada aktiva-aktiva jangka pendek-kas, sekuritas, persediaan dan piutang.

Dari definisi-definisi di atas dapat ditarik kesimpulan bahwa modal kerja adalah modal yang digunakan untuk melakukan kegiatan operasi perusahaan sebagai investasi yang ditanamkan dalam aktiva lancar atau aktiva jangka pendek yang berasal dari pinjaman jangka panjang maupun dari para pemilik untuk menghasilkan keuntungan (laba).

Menurut Munawir (2014:117), menyatakan bahwa:

Besar kecilnya modal kerja perusahaan merupakan fungsi dari berbagai faktor seperti:

1. Sifat atau tipe dari perusahaaan.

2. Waktu yang dibutuhkan untuk memprodusir atau memperoleh barang yang Akan dijual serta harga persatuan dari barang tersebut.

3. Syarat pembelian bahan atau barang dagangan.

4. Syarat penjualan.

5. Tingkat perputaran persediaan.
6. Faktor musiman, jumlah volume penjualan, tingkat perputaran piutang, dan jumlah rata-rata pengeluaran uang setiap harinya.

Begitu pula menurut Kasmir (2014:254) menyatakan bahwa:

Ada beberapa faktor yang mempengaruhi modal kerja yaitu:

1.Jenis perusahaan

Dalam prakteknya meliputi dua macam yaitu perusahaan yang bergerak dalam bidang jasa dan non jasa (industri), kebutuhan modal dalam perusahaan industri lebih besar jika dibandingkan dengan perusahaan jasa.

2.Syarat kredit

Syarat kredit atau penjualan yang pembayarannya dilakukan dengan cara mencicil (angsuran) juga sangat mempengaruhi modal kerja. Untuk meningkatkan penjualan bisa dilakukan dengan berbagai cara dan salah satunya adalah melalui penjualan secara kredit.

3. Waktu produksi

Artinya jangka waktu atau lamanya memproduksi suatu barang, makin lama waktu yang digunakan untuk memproduksi suatu barang, maka akan makin besar modal kerja yang dibutuhkan. Demikian pula sebaliknya makin pendek waktu yang dibutuhkan untuk memproduksi modal kerja maka makin kecil modal kerja yang dibutuhkan.

4. Tingkat perputaran persediaan 
Pengaruh tingkat perputaran persediaan terhadap modal kerja cukup penting bagi perusahaan. Semakin kecil atau rendah tingkat perputaran, kebutuhan.

\section{Penjualan}

Dalam perdagangan faktor kunci yang sangat menentukan dalam mendukung aktifitas usaha adalah penjualan. Faktor inilah yang menjadi kunci sekaligus indikator apakah suatu usaha perdagangan dapat dikatakaan mengalami kemajuan atau sebaliknya mengalami kemunduran. Penjualan adalah sebuah usaha atau langkah konkrit yang dilakukkaan untuk memindahkan suatu produk baik itu sebuah barang ataupun jasa, dari produsen kepada konsumen sebagai sasarannya.

Beberapa ahli mengungkapkan definisi penjualan yaitu sebagai berikut:

Menurut Irham Fahmi (2014:99) yang dikutip oleh Jumingan menyatakan bahwa:

"Penjualan merupakan penghasilan utama dari perusahaan dagang, perusahaan jasa, atau perusahaan industri, berupa hasil penjualan barang atau jasa kepada pembeli, langganan, penyewa, dan pemakai jasa lainnya”.

Menurut Bayu Swasta (2012:10) menyatakaan bahwa:

"Penjualan merupakan interaksi antar individu saling bertemu muka yang ditujukan untuk menciptakan, memperbaiki, menguasai atau mempertahankan hubungan pertukaran yang saling menguntungkan dengan pihak lain".

Menurut Herry (2014:123) menyatakaan bahwa:

"Penjualan merupakan total jumlah yang dibebankan kepada pelanggan atas barang dagangan yang dijual perusahan baik meliputi penjualan tunai maupun penjualaan secara kredit".

Dari ketiga pendapat di atas dapat disimpulkan bahwa penjualan adalah jumlah pendapatan perusahaaan yang berasal dari konsumen atas barang yang dijual secara tunai maupun kredit dengan cara kuantitas dikalikan harga jual.

Menurut Herry (2014:123) menyatakaan bahwa : "Penjualan merupakan total jumlah yang dibebankan kepada pelanggan atas barang dagangan yang dijual perusahan baik meliputi penjualan tunai maupun penjualaan secara kredit".

Menurut Sadono Sukirno (2011:238) besarnya total revenue dapat dihitung dengan cara:

$$
\mathrm{TR}=\mathrm{P} \times \mathrm{Q}
$$

Dimana:

$\mathrm{TR}=$ Jumlah hasil penjualan

$\mathrm{P}=$ Tingkat harga

Q = Jumlah barang

Pendapat lain dari Mulyadi (2012:67), yang menyatakan bahwa:

Penjualan = harga jumlah persatuan $\mathbf{x}$ volume produk yang dijual 


\section{Return On Asset}

Return On Asset (ROA) mengukur kemampuan manajemen dalam menghasilkan pendapatan dari pengelolaan asset perusahaan. Selain itu rasio ini digunakan untuk mengukur atau melihat tingkat kesehatan suatu perusahaan dalam menghasilan laba dari seluruh asset yang dimiliki perusahaan, semakin tinggi rasio ini maka semakin baik suatu perusahaan.

Menurut Mamduh M. Hanafi dan Abdul Halim (2014: 157) menyatakan bahwa:

"Return On Asset (ROA) adalah mengukur kemampuan perusahaan menghasilkan laba dengan menggunakan total asset (kekayaan) yang dipunyai perusahaan setelah disesuaikan dengan biaya-biaya untuk mendanai asset tersebut".

Menurut Sutrisno (2013: 229) menyatakan bahwa: "Return On Assets sering disebut sebagai rentabilitas ekonomi merupakan ukuran kemampuan perusahaan dalam menghasilkan laba dengan semua aktiva yang dimiliki oleh perusahaan”.

Menurut Martono (2013: 85) menyatakan bahwa:

"Return On Asset (ROA) adalah rasio yang digunakan untuk mengukur kemampuan perusahaan di dalam memperoleh laba dan efesiensi secara keseluruhan".

Berdasarkan pengertian para ahli di atas maka dapat ditarik kesimpulan bahwa Return On Asset digunakan oleh manajemen perusahaan untuk mengukur penggunaan manajemen perusahaan dalam memperoleh keuntungan secara keseluruhan. Semakin besar nilai Return On Asset suatu perusahaan, maka semakin besar pula tingkat keuntungan yang dicapai perusahaan tersebut dan semakin baik pula posisi perusahaan tersebut dari segi penggunaan asset.

Return On Asset merupakan ukuran seberapa besar laba yang dapat diperoleh dari seluruh kekayaan (aktiva) yang dimiliki perusahaan dan perusahaan yang tinggi menunjukan kemampuan perusahaan menghasilkan laba dimasa yang akan datang. Menurut Sutrisno (2013: 229) Indikator Return On Asset (ROA) yaitu:

1.Laba sebelum bunga dan pajak (EBIT) 2.Total Aktiva.

Menurut Martono (2013 : 85) yang menyatakan bahwa :

$$
\mathrm{ROA}=\frac{E B I T}{\text { Total Aktiva }} \times 100 \%
$$

Dikutip dari buku Analisis laporan keuangan Dasar-dasar pembelanjaan perusahaan Bambang Riyanto (2010: 57), yang menyatakan bahwa:

"Setiap perusahaan selalu membutuhkan modal kerja untuk membelanjai operasionalnya sehari-hari. Misalnya untuk memberikan persekot pembelian bahan mentah, membayar upah buruh, gaji pegawai dan lain sebagainnya. Dimana uang atau dana yang telah dikeluarkan itu diharapkan akan dapat kembali lagi masuk dalam perusahaan 
dalam waktu yang pendek melalui hasil penjualan produksinya".

Melihat penjelasan di atas, sudah jelas terdapat hubungan antara modal kerja dengan penjualan. Sebab modal kerja dan penjualan sangat mempengaruhi suatu perusahaan dalam mendukung suatu tujuan perusahaan yang ingin dicapai yaitu menghasilkan laba.

Dikutip dari buku Akuntansi Dasar 1\&2 Herry (2014 : 123), yang menyatakan bahwa: "Penjualan merupakan total jumlah yang dibebankan kepada pelanggan atas barang yang dijual perusahaan, baik meliputi penjualan tunai maupun secara kredit. Penjualan dikurangi dengan return \& penyesuaian harga jual dan potongan penjualan akan diperoleh penjualan bersih (net sales)".

Melihat penjelasan di atas, terdapat hubungan antara penjualan dengan Return On Assset. Untuk mengetahui ROA dapat diketahui melalui volume penjualan pada perusahaan tersebut. Semakin besar jumlah penjualan maka semakin besar pula pendapatan yang diperoleh perusahaan, namun laba yang diperoleh bukan tergantung dari seberapa besar jumlah penjualan tetapi juga dipengaruhi oleh sejauh mana perusahaan mampu menekan biaya sehingga akan meningkatkan laba yang akan berdampak pada profitabilitas perusahaan yang akan mempengaruhi besarnya return on asset (ROA) pada perusahaan.
Melihat semua penjelasan di atas, terdapat hubungan antara pengaruh modal kerja terhadap return on asset melalui penjualan. Pengelolaan Modal Kerja dalam perusahaan dan penjualan yang baik pula diharapkan akan dapat memaksimalkan tujuan dari perusahaan baik itu dalam memenuhi kebutuhan likuiditasnya, kemampuan untuk memenuhi kewajiban tepat waktu, melindungi perusahaan dari krisis modal serta memaksimalkan penggunaan aktiva lancar guna meningkatkan penjualan dan dalam memperoleh keuntungan (laba).

\section{Kerangka Pemikiran}

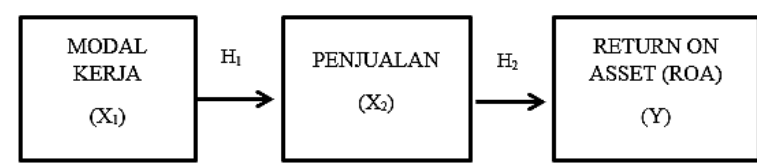

\section{Gambar 1. Desain Hipotesis Penelitian}

Berdasarkan kerangka pemikiran di atas peneliti mengajukan hipotesis yaitu bahwa diduga:

$\mathrm{H}_{1}$ : Modal kerja berpengaruh terhadap penjualan.

$\mathrm{H}_{2}$ : Penjualan berpengaruh terhadap Return On Asset.

\section{METODOLOGI PENELITIAN}

Metode dapat diartikan sebagai suatu cara untuk mencari, memperoleh, mengumpulkan atau mencatat data baik berupa data primer maupun data sekunder yang digunakan untuk keperluan menyusun suatu karya ilmiah dan kemudian dianalisa 
sehingga akan terdapat suatu kebenaran dari data yang diperoleh.

Menurut Sugiyono (2013:1), “metode penelitian pada dasarnya merupakan cara ilmiah untuk mendapatkan data dengan tujuan dan kegunaan tertentu. Berdasarkan hal tersebut terdapat empat kata kunci yang perlu diperhatikan yaitu cara ilmiah, data, tujuan dan kegunaan.”

Metode penelitian yang digunakan dalam penelitian ini adalah metode deskriptif dan asosiatif, yaitu suatu metode penelitian yang memberikan gambaran dan mengungkapkan suatu masalah yang terjadi pada saat penelitian berlangsung dengan mengumpulkan data dari PD. Sri Tanjung Indramayu dengan melihat laporan keuangan yang berupa laporan laba-rugi, neraca dan laporan keuangan pada perusahaan tersebut, sehingga dapat dibuat kesimpulan dan saran dengan tujuan untuk memberikan deskripsi yang sistematis dan akurat mengenai objek yang diteliti.

Menurut Sugiyono (2013:29) menjelaskan bahwa,"metode deskriptif adalah "penelitian yang dimaksudkan untuk menyelidiki keadaan, kondisi atau hal-hal lain yang sudah disebutkan, yang hasilnya dipaparkan dalam bentuk laporan penelitian". Penelitian deskriptif disini bertujuan untuk memperoleh gambaran mengenai adalah Modal Kerja, penjualan dan Return On Asset pada PD. Sri Tanjung Indramayu.
Sedangkan metode asosiatif menurut Sugiyono (2013: 89) bahwa, "metode asosiatif adalah suatu pernyataan yang menunjukan dugaan tentang hubungan antara dua variabel atau lebih". Dalam penelitian ini Akan diuji mengenai kebenaran hipotesis melalui pengumpulan data di lapangan apakah terdapat pengaruh adalah Modal Kerja, penjualan dan Return on Asset pada PD. Sri Tanjung Indramayu.

Tabel 2

\section{Indikator variabel dan pengukurannya}

\section{Kerangka Pemikiran}

\begin{tabular}{|l|l|}
\hline Variabel & Indikator \\
\hline $\begin{array}{l}\text { Independent } \\
\text { Modal kerja }\left(?_{1}\right)\end{array}$ & $\begin{array}{l}\text { 2. piutang } \\
\text { 3. surat berharga } \\
\text { 4. persediaan } \\
\text { kasmir (2014:210) }\end{array}$ \\
\hline $\begin{array}{l}\text { Independent } \\
\left.\text { Penjualan (? }{ }_{2}\right)\end{array}$ & $\begin{array}{l}\text { Total jumlah barang dagangan } \\
\text { pada perusahaan }\end{array}$ \\
\hline $\begin{array}{l}\text { Dependent } \\
\text { (Y) On Asset }\end{array}$ & $\begin{array}{l}\text { 1. Laba sebelum bunga dan } \\
\text { pajak (EBIT) } \\
\text { 2. Total Aktiva }\end{array}$ \\
\hline
\end{tabular}

\section{PEMBAHASAN}

\section{Kondisi keuangan PD. Sri Tanjung}

\section{Indramayu}

Tabel 3

Perkembangan Modal Sendiri pada PD Sri Tanjung Indramayu tahun 2010-2015

\begin{tabular}{|c|c|cc|c|}
\hline Tahun & Modal sendiri & \multicolumn{2}{|c|}{ Naik/turun } & perubahan \\
\hline 2010 & 3.964 .026 .000 & & - & - \\
\hline 2011 & 4.772 .000 .000 & $\mathrm{Rp}$ & 807.974 .000 & 20,38 \\
\hline 2012 & 4.415 .450 .000 & $\mathrm{Rp}$ & $(356.550 .000)$ & $(7,47)$ \\
\hline 2013 & 4.567 .660 .000 & $\mathrm{Rp}$ & 152.210 .000 & 3,45 \\
\hline 2014 & 5.488 .200 .000 & $\mathrm{Rp}$ & 920.540 .000 & 20,15 \\
\hline 2015 & 5.819 .000 .000 & $\mathrm{Rp}$ & 330.800 .000 & 6,03 \\
\hline$\sum$ & $29,026,336,000$ & & - & - \\
\hline $\begin{array}{c}\text { Rata- } \\
\text { rata }\end{array}$ & $4,837,722,667$ & & - & - \\
\hline
\end{tabular}


Tabel 4

Perkembangan Aktiva Lancar \& Total Aktiva pada PD Sri Tanjung Indramayu 2010-2015

\begin{tabular}{|c|c|c|}
\hline Tahun & Modal sendiri & Total Aktiva \\
\hline 2010 & 1.210 .026 .000 & 6.164 .026 .000 \\
\hline 2011 & 1.322 .000 .000 & 6.422 .000 .000 \\
\hline 2012 & 1.762 .000 .000 & 6.917 .000 .000 \\
\hline 2013 & 2.052 .000 .000 & 7.372 .000 .000 \\
\hline 2014 & 2.564 .800 .000 & 8.074 .800 .000 \\
\hline 2015 & 3.065 .000 .000 & 8.219 .000 .000 \\
\hline$\sum$ & 11.975 .826 .000 & 43168.826 .000 \\
\hline $\begin{array}{c}\text { Rata- } \\
\text { rata }\end{array}$ & 1.995 .971 .000 & 7.194 .804 .333 \\
\hline
\end{tabular}

Perkembangan Modal kerja pada PD. Sri Tanjung Indramayu

\section{Tabel 5}

perhitungan modal kerja pada PD. Sri

Tanjung Indramayu

tahun 2010 - 2015

\begin{tabular}{|c|c|c|c|c|c|}
\hline Tahun & $\begin{array}{c}\text { Kas } \\
(\mathrm{Rp})\end{array}$ & $\begin{array}{c}\text { Piutang } \\
(\mathrm{Rp})\end{array}$ & $\begin{array}{c}\text { persediaan } \\
(\mathrm{Rp})\end{array}$ & $\begin{array}{c}\text { perlengkapan } \\
(\mathrm{Rp})\end{array}$ & jumlah \\
\hline 2010 & 200.000 .000 & 240.000 .000 & 500.026 .000 & 270.000 .000 & 1.210 .026 .000 \\
\hline 2011 & 237.000 .000 & 185.000 .000 & 650.000 .000 & 250.000 .000 & 1.322 .000 .000 \\
\hline 2012 & 325.000 .000 & 250.000 .000 & 987.000 .000 & 200.000 .000 & 1.762 .000 .000 \\
\hline 2013 & 610.000 .000 & 385.000 .000 & 687.000 .000 & 370.000 .000 & 2.052 .000 .000 \\
\hline 2014 & 850.000 .000 & 514.200 .000 & 900.000 .000 & 300.600 .000 & 2.564 .800 .000 \\
\hline 2015 & 950.000 .000 & 475.000 .000 & 815.000 .000 & 825.000 .000 & 3.065 .000 .000 \\
\hline$\sum$ & 3.172 .000 .000 & 2.049 .200 .000 & 4.539 .026 .000 & 2.215 .600 .000 & 11.975 .826 .000 \\
\hline $\begin{array}{c}\text { rata- } \\
\text { rata }\end{array}$ & 528.666 .667 & 341.533 .333 & 756.504 .333 & 369.266 .667 & 1.995 .971 .000 \\
\hline
\end{tabular}

Perkembangan penjualan pada PD. Sri

Tanjung Indramayu

\section{Tabel 6}

Perhitungan penjualan PD. Sri Tanjung Indramayu tahun 2010 -2015

\begin{tabular}{|c|c|c|}
\hline Tahun & $\begin{array}{c}\text { Penjualan Bersih } \\
(\mathrm{Rp})\end{array}$ & $\begin{array}{c}\text { Naik/ Turun } \\
(\mathrm{Rp})\end{array}$ \\
\hline 2010 & 5.039 .500 .000 & \\
\hline 2011 & 5.640 .000 .000 & 600.500 .000 \\
\hline 2012 & 6.800 .000 .000 & 1.160 .000 .000 \\
\hline 2013 & 7.040 .400 .000 & 240.400 .000 \\
\hline 2014 & 7.269 .500 .000 & 229.100 .000 \\
\hline 2015 & 7.465 .000 .000 & 195.500 .000 \\
\hline$\sum$ & 39.254 .400 .000 & - \\
\hline rata-rata & 6.542 .400 .000 & - \\
\hline
\end{tabular}

Tabel 7

Perhitungan Return On Asset (ROA)

pada PD. Sri Tanjung Indramayu

tahun 2010 - 2015

\begin{tabular}{|c|c|c|c|}
\hline Tahun & $\begin{array}{c}\text { EBIT } \\
(\mathrm{Rp})\end{array}$ & $\begin{array}{c}\text { Total Aktiva } \\
(\mathrm{Rp})\end{array}$ & $\begin{array}{c}\text { Return On } \\
\text { Asset } \\
\%\end{array}$ \\
\hline 2010 & 1.500 .526 .000 & 6.164 .026 .000 & 24,34 \\
\hline 2011 & 1.856 .740 .000 & 6.422 .000 .000 & 28,91 \\
\hline 2012 & 2.190 .500 .000 & 6.917 .000 .000 & 31,66 \\
\hline 2013 & 2.597 .400 .000 & 7.372 .000 .000 & 35,23 \\
\hline 2014 & 2.679 .500 .000 & 8.074 .800 .000 & 33,18 \\
\hline 2015 & 2.814 .000 .000 & 8.219 .000 .000 & 34,23 \\
\hline$\sum$ & 13.638 .666 .000 & - & - \\
\hline rata- rata & 2.273 .111 .000 & - & - \\
\hline
\end{tabular}

Analisis koefisien korelasi

Analisis koefisien korelasi antara X1

(Modal kerja) terhadap X2 (Penjualan)

Tabel 8

Tabel penolong untuk analisis korelasi X1 (Modal kerja) terhadap X2 (Penjualan)

(Dalam jutaan)

\begin{tabular}{|c|c|c|c|c|c|}
\hline $\mathrm{N}$ & $\mathrm{X}_{1}$ & $\mathrm{X}_{2}$ & $\mathrm{X}_{1}{ }^{2}$ & $\mathrm{X}_{2}{ }^{2}$ & $\mathrm{X}_{1} \mathrm{X}_{2}$ \\
\hline 1 & 1.210 & 5.039 & 1.464 .100 & 25.391 .521 & 6.097 .190 \\
\hline 2 & 1.322 & 5.640 & 1.747 .684 & 31.809 .600 & 7.456 .080 \\
\hline 3 & 1.762 & 6.800 & 3.104 .644 & 46.240 .000 & 11.981 .600 \\
\hline 4 & 2.052 & 7.040 & 4.210 .704 & 49.561 .600 & 14.446 .080 \\
\hline 5 & 2.564 & 7.269 & 6.574 .096 & 52.838 .361 & 18.637 .716 \\
\hline 6 & 3.065 & 7.465 & 9.394 .225 & 55.726 .225 & 22.880 .225 \\
\hline Jumlah & 11.975 & 39.253 & 26.495 .453 & 261.567 .307 & 81.498 .891 \\
\hline
\end{tabular}

$$
\begin{gathered}
r=\frac{n\left(\sum X_{1} X_{2}\right)-\left(\sum X_{1}\right)\left(\sum X_{2}\right)}{\sqrt{\left[n \sum X_{1}^{2}-\left(\sum X_{1}\right)^{2}\right]\left[n \sum X_{2}^{2}-\left(\sum X_{2}\right)^{2}\right]}} \\
=\frac{6(81.498 .891)-(11.975)(39.253)}{\sqrt{\left[6(26.495 .453)-(11.975)^{2}\right]\left[6(261.567 .307)-(39.253)^{2}\right]}} \\
=\frac{488.993 .346-470054675}{\sqrt{(158.972 .718-143.400 .625)(1.569 .403 .842-1.540 .789 .009)}} \\
=\frac{18.938 .671}{\sqrt{(15.572 .093)(28.614 .833)}} \\
=\frac{18.938 .671}{\sqrt{(445.592 .840 .655 .469)}} \\
21.109 .070 \quad=\mathbf{0 . 8 9 7}
\end{gathered}
$$


Analisis koefisien korelasi Penjualan terhadap Return On Asset

Tabel 9

Tabel penolong untuk analisis korelasi $\mathbf{X}_{2}$ (Penjualan)

\section{Terhadap Y(Return On Asset)} (Dalam jutaan)

\begin{tabular}{|c|c|c|c|c|c|}
\hline $\mathrm{N}$ & $\mathrm{X}_{2}$ & $\mathrm{Y}$ & $\mathrm{X}_{2}{ }^{2}$ & $\mathrm{Y}^{2}$ & $\mathrm{X}_{2} \mathrm{Y}$ \\
\hline 1 & 50.39 & 24.34 & 2539.15 & 592.44 & 1226.49 \\
\hline 2 & 56.40 & 28.91 & 3180.96 & 835.79 & 1630.52 \\
\hline 3 & 68.00 & 31.66 & 4624.00 & 1002.36 & 2152.88 \\
\hline 4 & 70.40 & 35.23 & 4956.16 & 1241.15 & 2480.19 \\
\hline 5 & 72.69 & 33.18 & 5283.83 & 1100.91 & 2411.85 \\
\hline 6 & 74.65 & 34.23 & 5572.62 & 1171.69 & 2555.27 \\
\hline Jumlah & 392.53 & 187.55 & 26156.73 & 5944.34 & 12457.21 \\
\hline
\end{tabular}

$$
r=\frac{n\left(\sum X_{2} Y\right)-\left(\sum X_{2}\right)\left(\sum Y\right)}{\sqrt{\left[n \sum X_{2}^{2}-\left(\sum X_{2}\right)^{2}\right]\left[n \sum Y^{2}-\left(\sum Y\right)^{2}\right]}}
$$

$$
=\frac{6(12457.21)-(39.253)(187.55)}{\sqrt{\left[6(26156.73)-(39.253)^{2}\right]\left[6(5944.34)-(187.55)^{2}\right]}}
$$

$=\frac{747443.27-73619}{\sqrt{(156940.4-154079.8)(3566.03-35175)}}$

$$
\begin{aligned}
& =\frac{1124.272}{\sqrt{(2860.583)(491.0225)}} \\
& =\frac{1124.272}{\sqrt{(14046.11)}} \\
& =\frac{1124.272}{1.185 .16} \\
& =\mathbf{0 . 9 4 8}
\end{aligned}
$$

\section{Analisis koefisien determinasi besarnya} modal kerja terhadap penjualan

Untuk mengukur berapa besar kontribusi pegaruh modal kerja terhadap penjualan, maka digunakan perhitungan koefisien determinan yaitu sebagai berikut :

$$
\begin{aligned}
\boldsymbol{K d} & =\boldsymbol{r}^{2} \times \mathbf{1 0 0 \%} \\
& =0.897^{2} \times 100 \% \\
\mathbf{K d} & =\mathbf{8 0 . 4 6 \%}
\end{aligned}
$$

Berdasarkan perhitungan di atas dapat diketahui bahwa presentase atau kontribusi yang diberikan modal kerja terhadap penjualan pada PD. Sri Tanjung Indramayu adalah sebesar $\mathbf{8 0 . 4 6 \%}$ sedangkan sisanya 19.54\% diberikan oleh faktor lain yang tidak diteliti dalam penelitian ini.

\section{Analisis koefisien determinasi besarnya penjualan terhadap Return on asset (ROA)}

Berdasarkan data yang diperoleh untuk mengetahui presentase pengaruh penjualan terhadap return on asset pada PD. Sri Tanjung Indramayu digunakan koefisien determinasi yaitu sebagai berikut :

$$
\begin{aligned}
\boldsymbol{K d} & =\boldsymbol{r}^{2} \times \mathbf{1 0 0 \%} \\
& =0.948^{2} \times 100 \% \\
\mathbf{K d} & =\mathbf{8 9 . 8 7 \%}
\end{aligned}
$$

Berdasarkan perhitungan di atas dapat diketahui bahwa presentase atau kontribusi yang diberikan penjualan terhadap return on asset pada PD. Sri Tanjung Indramayu adalah sebesar $\mathbf{8 9 . 8 7 \%}$ sedangkan sisanya $\mathbf{1 0 . 1 3 \%}$ diberikan oleh faktor lain yang tidak diteliti dalam penelitian ini.

\section{Uji Hipotesis (Uji t)}

Uji t hipotesis pengaruh $X_{1}$ (Modal kerja) terhadap $\mathrm{X}_{2}$ (Penjualan)

Berdasarkan data yang diperoleh maka besarnya $t_{h i t u n g}$ adalah sebagai berikut : 


$$
\begin{aligned}
& \mathrm{t}=r \frac{\sqrt{n-2}}{\sqrt{1-r^{2}}} \\
& \mathrm{t}=0.897 \frac{\sqrt{6-2}}{\sqrt{1-(0.897)^{2}}} \\
& \mathrm{t}=0.897 \frac{2}{0.442} \\
& \mathrm{t}=0.897 \times 4.524 \\
& \mathbf{t}=\mathbf{4 . 0 5 8}
\end{aligned}
$$

Berdasarkan perhitungan di atas, diketahui $t_{\text {hitung }}$ sebesar 4.058 digunakan uji dua pihak, dengan taraf signifikan 5\% dan derajat kebebasan (dk) 6-2 = 4 didapatkan nilai $t_{\text {tabel }}$ sebesar 2.776 karena $t_{\text {hitung }}>$ $t_{\text {tabel }}(4.058>2.776)$, maka HO di tolak dan Ha di terima,yang menyatakan bahwa modal kerja berpengaruh terhadap penjualan pada PD. Sri Tanjung Indramayu.

\section{Gambar 10}

Uji hipotesis dua pihak $X_{1}$ terhadap $X_{2}$

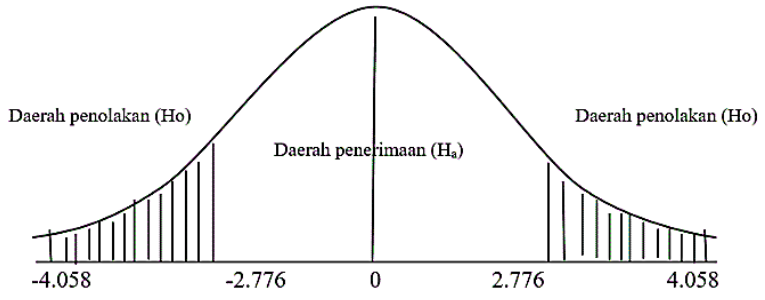

\section{Uji t hipotesis Pengaruh X2 (Penjualan)}

\section{terhadap Y (Return On Asset)}

Berdasarkan data yang diperoleh maka besarnya $t_{\text {hitung }}$ adalah sebagai berikut:

$$
\begin{aligned}
& \mathrm{t}=r \frac{\sqrt{n-2}}{\sqrt{1-r^{2}}} \\
& \mathrm{t}=0.948 \frac{\sqrt{6-2}}{\sqrt{1-(0.948)^{2}}} \\
& \mathrm{t}=0.948 \frac{2}{0.318} \\
& \mathrm{t}=0.948 \times 6.289
\end{aligned}
$$

$$
\mathbf{t}=\mathbf{5 . 9 6 1}
$$

Berdasarkan perhitungan di atas, diketahui $\mathrm{t}_{\text {hitung }}$ sebesar 5.961 digunakan uji dua pihak, dengan taraf signifikan 5\% dan derajat kebebasan (dk) 6-2 = 4 didapatkan nilai $t_{\text {tabel }}$ sebesar 2.776 karena $t_{\text {hitung }}>t_{\text {tabel }}$ (5.961 > 2.776), maka $\mathrm{H}_{2} \mathrm{O}$ di tolak dan $\mathrm{H}_{2}$ a di terima, yang menyatakan bahwa penjualan berpengaruh terhadap Return On asset pada PD. Sri Tanjung Indramayu.

\section{Gambar 11}

\section{Uji hipotesis dua pihak $\mathrm{X}_{2}$ terhadap $\mathrm{Y}$}

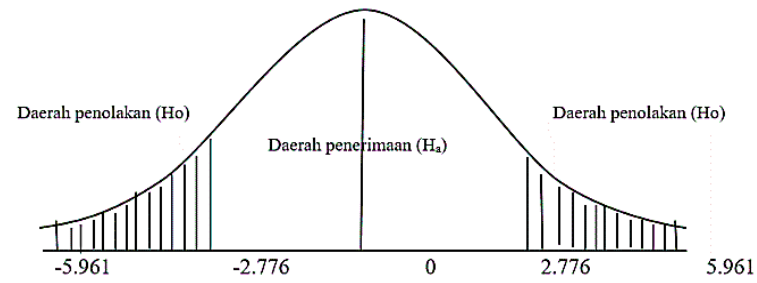

\section{KESIMPULAN}

1. Berdasarkan hasil analisis Modal Kerja terhadap Penjualan diperoleh koefisien korelasi sebesar 0.897 yang berarti antara modal kerja terhadap penjualan mempunyai hubungan yang sangat kuat. Koefisien determinasi Modal kerja terhadap Penjualan adalah $80.46 \%$. artinya kontribusi yang diberikan modal kerja terhadap penjualan mencapai $80.46 \%$ dan sisanya $19.54 \%$ dipengaruhi oleh variabel lain yang tidak diteliti. Dari hasil perhitungan uji hipotesis Modal Kerja $\left(X_{1}\right)$ terhadap Penjualan $\left(X_{2}\right)$ maka diperoleh $t_{\text {hitung }}$ sebesar 4.058 digunakan uji dua pihak, dengan taraf signifikan 5\% dan derajat kebebasan (dk) 
6-2 = 4 didapatkan nilai $t_{\text {tabel }}$ sebesar 2.776 karena $t_{\text {hitung }}>t_{\text {tabel }}(4.058>$ 2.776), maka $\mathrm{H}_{1} \mathrm{O}$ di tolak dan $\mathrm{H}_{1}$ a di terima artinya terdapat Pengaruh antara Modal kerja terhadap Penjualan.

2. Berdasarkan hasil analisis Penjualan $\left(\mathrm{X}_{2}\right.$ ) terhadap Return On Asset (Y) diperoleh koefisien korelasi sebesar 0.948 yang berarti antara penjualan $\left(\mathrm{X}_{2}\right)$ terhadap Return on asset (Y) mempunyai hubungan yang sangat kuat. Koefisien determinasi Penjualan $\left(\mathrm{X}_{2}\right)$ terhadap Return On Asset (Y) adalah $89.87 \%$. artinya kontribusi yang diberikan Penjualan $\left(\mathrm{X}_{2}\right)$ terhadap Return On Asset (Y) mencapai $89.87 \%$ dan sisanya 10.13 $\%$ dipengaruhi oleh variabel lain yang tidak diteliti. Dari hasil perhitungan uji hipotesis $t$ Penjualan $\left(\mathrm{X}_{2}\right)$ terhadap Return On Asset (Y) maka thitung sebesar 5.961 digunakan uji dua pihak, dengan taraf signifikan 5\% dan derajat kebebasan $(\mathrm{dk})$ 6-2 = 4 didapatkan nilai $t_{\text {tabel }}$ sebesar 2.776 karena $t_{\text {hitung }}>$ $t_{\text {tabel }}(5.961>2.776)$, maka $\mathrm{H}_{2} \mathrm{O}$ di tolak dan $\mathrm{H}_{2} \mathrm{a}$ di terima artinya terdapat pengaruh antara penjualan terhadap Return On asset.

\section{Saran}

Dari kesimpulan di atas, peneliti mengajukan saran kepada pihak PD. Sri Tanjung Indramayu yaitu sebagai berikut :
1. PD. Sri Tanjung Indramayu diharapkan dapat mengelola penggunaan modal kerja pada perusahaan dengan efektif dan efisien guna meningkatkan penggunaan dana yang lebih tepat dan memperoleh laba yang maksimal dari penjualan.

2. PD. Sri Tanjung Indramayu diharapkan dapat lebih memaksimalkan hasil penjualan tersebut agar perusahaan dapat memperoleh laba yang maksimal sesuai yang diharapkan perusahaan baik dalam memenuhi likuiditasnya atau untuk mempertahankan kelangsungan hidup perusahaan.

\section{DAFTAR PUSTAKA}

Fahmi, Irham.2014. Analisi laporan keuangan. Bandung: ALFABETA.

Herry. 2014. Akuntansi Dasar 1 \&2. Jakarta: Grasindo.

Kasmir. 2014. Analisis Laporan Keuangan. Jakarta: Raja Grafindo Persado.

Mamduh M.Hanafi M.B.A. dan Prof. Dr. Abdul Halim, M.B.A.,AKT. 2014. Analisis laporan

keuangan.Yogyakarta: UPP STIM YKPN.

Martono. 2013. BANK \& Lembaga Keuangan Lain. Yogyakarta:EKONISA.

Marisa ambarita. 2009. Pengaruh Modal Kerja terhadap Return On Asset (ROA) pada perusahaan barang konsumsi yang terdaftar dibursa efek indonesia. Jurnal Universitas sumatra utara.Medan: tidak diterbitkan. 
Megi Wulan Rahayu, Ira Phajar Lestari. 2009.

Pengaruh hasil penjualan terhadap laba bersih pada PT BENTOEL INTERNASIONAL

INVESTAMA.TBK. Jurnal

Universitas Gunadarma.

Depok: Tidak diterbitkan.

Mulyadi. 2012. AKUNTANSI BIAYA.

Yogyakarta: Sekolah tinggi ilmu manajemen YKPN.

Munawir,S. 2014. Analisis Laporan Keuangan. Yogyakarta: LIBERTY YOGYAKARTA.

Riyanto, Bambang.2014. Dasar dasar pembelanjaan Perusahaan. Yogyakarta: BPFE Yogyakarta.

Sonnya Nurman Sasongko. 2009. Pengaruh Modal kerja dan volume penjualan terhadap laba bersih (studi kasus pada perusahaan industri logam terdaftar di BEI tahun 2010-2012). Jurnal

Universitas Komputer Indonesia. Bandung : tidak diterbitkan.

Sugiyono. 2012. Statistika untuk penelitian. Bandung: ALFABETA.

Sukirno, Sadono. 2011. Micro Ekonomi Teori Pengantar Edisi ketiga. Jakarta:Rajawali pers

Sutrisno.2013. Manajemen Keuangan " Teori konsep \& Aplikasi”. Yogyakarta:EKONISA.

Swasta, Bayu. 2012. Manajemen penjualan (Edisi 3). Yogyakarta:BPFE.

Jurnal :

http://repository.usu.ac.id/handle/12356789/ 23898

http://ebookbrowsee.net/gunadarma2026604.ssm-fe-pdf-d2951652

http://repository.widyatama.ac.id/xmlui/bitstr eam/handle/10364/466/0100246.pdf?se quence $=1=$ 